ОСОБЛИВОСТІ ОРГАНІЗАЦІї ТА ШЛЯХИ УДОСКОНАЛЕННЯ

САМОСТІЙНОГО НЕСЕННЯ СЛУЖБИ З ОХОРОНИ ГРОМАДСЬКОГО ПОРЯДКУ ЧАСТИНАМИ, ПІДРОЗДІЛАМИ НАЦІОНАЛЬНОЇ ГВАРДІЇ УКРАЇНИ

PECULIARITIES OF THE ORGANIZATION OF INDEPENDENT PERFORMANCE OF THE SERVICE OF THE PUBLIC ORDER PROTECTION BY UNITS OF NGU AND WAYS OF ITS IMPROVEMENT

УдК 355.4

DOI https://doi.org/10.32843/

pma2663-5240-2020.20.21

\section{Пташка С.Д.}

старший викладач

кафедри тактико-спеціальної підготовки

Національна академія

Національної гвардії України

\section{Кулешов О.П.}

старший викладач

кафредри тактико-спеціальної підготовки

Національна академія

Національної гвардії України

Коломієць I.I.

курсант гуманітарного факультету

Національна академія

Національної гвардії України у статті розглядаються особливості організації самостійного несення служби з охорони громадського порядку й надаються пропозиції щодо оптимізації службової діяльності Національної гвардії України з виконання завдань з охорони громадського порядку на маршрутах патрулювання, а саме: оперативного розв'язання питань по затриманню порушників громадського порядку, оформленню відповідних документів, доставлення підозрюваних у скоєнні злочинів і правопорушень у відділ Національної поліції. Розглянуто й проаналізовано зміст, сутність нормативно-правових актів, що регулюють питання з організації самостійного несення служби з охорони громадського порядку частинами й підрозділами Національної гвардії України. Описано актуальні проблеми забезпечення самостійного несення служби підрозділами Національної гвардії України та їх вплив на виконання завдань з охорони громадського порядку. 3 метою посилення заходів щодо забезпечення охорони громадського порядку й громадської безпеки, оперативного реагування на повідомлення про кримінальні правопорушення та інші події, недопущення дестабілізації оперативної обстановки, вчинення протиправних дій запропоновані шляхи вдосконалення правових та організачійних питань щодо забезпечення безпеки й порядку на маршрутах патрулювання Національної гвардії України.

На основі проведеного аналізу й вивчення досвіду несення служби з охорони громадського порядку в нашій державі й враховуючи, що особовий склад Національної гвардії України вперше залучається до самостійного несення служби з охорони громадського порядку (до цього часу гвардійці несли службу спільно зі співробітниками Національної поліції), першочерговим напрямом $\epsilon$ підвищення їх мобільності щодо своєчасного реагування на зміни оперативної обстановки на території обслуговування. У зв'язку із цим на початку самостійного несення служби військовослужбовцями Національної гвардії України необхідне забезпечення відповідним екіпіруванням, оснащення транспортом і сучасними засобами зв'язку, а також закріплення працівника поліції за військовими нарядами в зоні оперативного реагування під час несення служби, що дасть можливість для своєчасної допомоги в розв'язанні проблемних питань під час різкої зміни обстановки.

Ключові слова: охорона громадського порядку, патрульна служба, зона оперативного реагування, органи правопорядку, маршрут патрулювання.

The article considers the peculiarities of the organization of independent service with the $P O P$ and provides proposals for optimizing the activities of the National Guard of Ukraine to perform tasks of public order on patrol routes, namely: appointment and assignment of police officers to the area (areas, zones prompt response), while serving in the military units of the NGU, as well as prompt resolution of issues of detention, execution of relevant documents, delivery of suspects in crimes and offenses to the National Police Department. The content, essence of normative-legal acts regulating the issues of organization of independent service of public order protection by units and subunits of the National Guard of Ukraine are considered and analyzed. The actual problems of ensuring independent service with the POP by the units of the National Guard of Ukraine and the peculiarities of their implementation are described. In order to strengthen measures to ensure public order and public safety, prompt response to reports of criminal offenses and other events, to prevent destabilization of the operational situation, illegal actions, specific ways to improve legal and organizational issues to ensure security and order on patrol routes by the National Guard of Ukraine. Based on the analysis and study of experience in the independent implementation of tasks for the public order protection in our country and taking into account, that the NGU personnel are involved in self-service with the POP for the first time, so far the Guardsmen have served together with the National Police, it is equally important to increase its mobility in terms of timely response to changes in the operational situation in the service area. Therefore, during the initial period of independent service by NGU servicemen, it is necessary to provide appropriate equipment, transport and modern means of communication, as well as to secure a police officer in the operational response zone during service, which will provide timely assistance in resolving problematic issues at sharp changes of a situation. Key words: public order protection (POP), patrol service, operational response zone, law enforcement agencies, patrol route.
Постановка проблеми в загальному вигляді. Гострота питань охорони громадського порядку й забезпечення громадської безпеки в державі визначається зростанням криміногенного потенціалу в усіх сферах громадського життя, зумовленого насамперед негативними процесами, пов'язаними з пере- ходом до нових суспільних відносин, кризовими явищами в економіці, зміною старих механізмів соціального управління та іншими не менш негативними проявами. Одним із провідних напрямів адміністративної діяльності $€$ забезпечення громадського порядку й громадської безпеки. Водночас важлива роль у вико- 
нанні цього завдання відводиться саме підрозділам патрульної служби поліції та підрозділам Національної гвардії України (далі - НГУ).

Натепер питання ефективної організації охорони громадського порядку цими підрозділами залишаються нерозв'язаними в Україні, адже й раніше науковцями висловлювалась думка про актуальну необхідність кардинальної перебудови патрульної служби. I першочерговим завданням є збільшення чисельності патрульних підрозділів до необхідного рівня та створення в зонах обслуговування відповідної кількості маршрутів патрулювання, мобільних груп, груп своєчасного реагування та надання допомоги військовим нарядам у затриманні порушників (злочинців), оформленні документів і доставлянні в територіальні органи (відділи) Національної поліції.

Сутність проблеми під час несення служби з охорони громадського порядку частинами й підрозділами Національної гвардії України полягає в тому, що з 1 серпня 2019 р. підрозділи НГУ виконують завдання з охорони громадського порядку в складі самостійних піших патрулів. До цього гвардійці несли службу спільнозі співробітниками Національної поліції.

У зв'язку із цим назріла потреба дослідити порядок організації та виконання завдань частинами, підрозділами НГУ під час самостійного несення служби з охорони громадського порядку (далі - ОГП) на маршрутах патрулювання, а також визначити проблемні питання та шляхи їх розв'язання.

Аналіз останніх досліджень і публікацій. Порядок організації та несення служби з ОГП визначено в Наказі Міністерства внутрішніх справ України № 1089 від 24 грудня 2019 р. «Про затвердження Інструкції про організацію та несення служби з охорони громадського порядку й забезпечення громадської безпеки військовими частинами (підрозділами) Національної гвардії України» [1, с. 2] і в Наказі Міністра внутрішніх Справ України від 16 червня 2014 р. № 567 «Про затвердження Положення про військові частини й підрозділи з охорони громадського порядку Національної гвардії України» [2, с. 4]. Виходячи з особливостей несення служби, розглянуто наявні й запропоновано нові шляхи з організації виконання цих завдань, але, на жаль, питанню організації самостійного несення служби з ОГП частинами, підрозділами НГУ й визначенню їхніх повноважень не приділялось належної уваги.

Особливості організації та виконання службово-бойових завдань військовими нарядами на маршрутах патрулювання з ОГП і проблеми в цій сфері досліджувалися в наукових працях таких учених (передусім фахівців у галузі адміністративного права), як О.М. Бандурка, О.І. Безпалова, В.О. Іванцов, О.О. Книженко, П.Ю. Корнієць, А.М. Кучук, О.М. Литвинов, М.В. Лошицький , О.М. Музичук, Д.О. Горбач та інші.

у своїх дослідженнях вони наголошують на тому, що організація патрульної служби надзвичайно складна, оскільки обов'язки патрульних різноманітні. Патрульна служба часто повинна вдаватися до превентивних заходів, профілактично присікаючи небезпечні злочини не лише в їхньому фактичному прояві, але й на стадії виникнення потенційної їхньої можливості. Окрім того, саме патрульна служба першою опиняється на місці злочинів, а отже, має забезпечити реалізацію хоча б початкових заходів на місці події до прибуття слідчо-оперативної групи.

Проте, незважаючи на активізацію наукових досліджень, питання щодо забезпечення громадського порядку й практичної діяльності НГУ в цій сфері не знайшли свого належного викладення.

У ході проведеного аналізу й вивчення досвіду організації служби з ОГП у нашій державі й провідних державах Європи, світу визначені проблемні питання щодо підвищення ефективності взаємодії між військовими нарядами, надання своєчасної допомоги по затриманню, оформленню документів і доставляння порушників (злочинців) громадського порядку у відділ національної поліції під час самостійного несення служби підрозділами НГУ.

У зв'язку із цим у статті надаються пропозиції командирам частин, підрозділів НГУ щодо погодження та розв'язання цих проблемних питань з організації самостійного несення служби й шляхів їх удосконалення.

Мета статті. Головною метою роботи $€$ визначення проблемних питань, які впливають на якість організації служби з ОГП частинами й підрозділами НГУ під час самостійного несення служби військовими нарядами на маршрутах патрулювання та пропонування можливих шляхів для їх розв'язання.

Виклад основного матеріалу. Охорона громадського порядку здійснюється цілою низкою стройовихпідрозділів поліції з відповідними апаратами управління, які мають визначену організаційну структуру, що призвана закріпити за її складовими частинами комплекс завдань і функцій, необхідних для успішної діяльності по ОГП і боротьбі зі злочинністю.

Серед сил, залучених для ОГП і забезпечення безпеки, які беруть безпосередню участь у здійсненні патрульної служби (далі - ПС) і найбільш близькі за своїми функціями до стройових підрозділів поліції, $€$ вій- 
ськові частини, підрозділи НГУ відповідно до Закону України «Про національну гвардію України» [3, с. 1]. Правоохоронні органи й військові частини, підрозділи НГУ діють у різних умовах, що викликані явищами соціального, природного, техногенного характеру.

У зв'язку з постійним обміном досвідом з аналогічними структурами провідних європейських держав частини, підрозділи НГУ намагаються відповідати міжнародним стандартам й нормам у підтримці публічної безпеки. На основі цих міжнародних стандартів з 1 серпня 2019 р. військовослужбовці НГУ приступили до виконання завдань з охорони громадського порядку в складі самостійних піших патрулів.

За словами командувача НГУ, самостійне несення служби з охорони громадського порядку військовими правоохоронцями $є$ досить поширеним серед споріднених формувань країн Європи явищем.

Модель самостійного патрулювання військових дуже поширена в аналогічних структурах Європи, зокрема в тих, які входять до Міжнародної асоціації сил жандармерії та поліції в статусі військової установи FIEP. Національна гвардія України є повноправним членом цієї організації ще з 2017 р.

Національна гвардія України залучалась до патрулювання вулиць і раніше. Організація та планування маршрутів патрулювання проводилося залежно від криміногенної ситуації в конкретному населеному пункті, де становище напруженіше. Але серед людей все більше виникають запитання: які права й обов'язки військовослужбовців під час подібних патрулювань, які дії вони можуть вчиняти, як слід поводитися у випадку потрапляння в ситуацію, коли військовослужбовець Національної гвардії застосовує чи має намір застосувати щодо Вас поліцейські заходи.

Розглянемодетальніше, якізаходипередбачені щодо виконання та забезпечення підрозділів НГУ щодо самостійного несення служби з ОГП та які повноваження їм надаються.

Відповідно до Доручення Міністра внутрішніх справ [4, с. 1, 2], для забезпечення виконання завдань частинами, підрозділами НГу щодо самостійного несення служби з охорони громадського порядку в межахтериторії обслуговування за дорученням Міністра внутрішніх справ України передбачено виконання таких заходів: забезпечення чергових військових нарядів (далі - ЧВН), начальників військових нарядів (далі - НВН) планшетними пристроями, які підключенні до інформаційно-телекомунікаційної системи «нформаційний портал Національної поліції України» з рівнем доступу до цієї системи; радіостанціями, які працюють у радіомережі територіальних органів (підрозділів) поліції, та навчання ними користуватися; оснащення ЧВН, НВН, патрульнихзі складу офіцерів, військовослужбовців військової служби за контрактом табельною зброєю з двома спорядженими магазинами, військовослужбовців строкової служби - виключно пристроями для вистрілу гумових куль із двома спорядженими магазинами; екіпіровкою військових нарядів спеціальними засобами.

Для організації несення служби з охорони громадського порядку частинами, підрозділами НГУ в кожному територіальному управлінні національної поліції відпрацьовуються плани єдиної дислокації маршрутів, затверджуються керівником територіального органу поліції та надсилаються до військової частини.

3 урахуванням стану оперативної обстановки до нього вносяться необхідні зміни, які дозволяють об'єднати можливості стройових підрозділів поліції, частин, підрозділів НГУ, державної служби охорони (далі - ДСО) й інших сил із метою узгодженого й ефективного їх використання в ОГП і боротьбі зі злочинністю.

Відповідно до Наказу Міністерства внутрішніх справ [5, с. 1] основною формою організації служби з ОГП для частин, підрозділів НГУ є план залучення сил і засобів, який затверджується командиром військової частини НГУ й погоджується з начальником територіального органу поліції в межах території його обслуговування.

Виконання завдань здійснюється на підставі підписаного начальником головного управління Національної поліції письмового запиту на ім'я начальника оперативного територіального об'єднання НГУ про виділення сил і засобів НГУ в межах області, де дислокується військова частина НГУ, зони відповідальності (оперативного реагування) цього оперативно-територіального об'єднання НГУ.

Згідно 3 Наказом Міністерства внутрішніх справ [1, с. 1] для самостійного несення служби з ОГП підрозділам НГУ керівництвом Національної поліції визначені території обслуговування та зони оперативного реагування.

Дні й час несення служби в зонах оперативного реагування, конкретні точки несення служби (далі - НГВН), кількість змін, екіпірування з урахуванням оперативної обстановки визначаються керівником органу Національної поліції за погодженням із командиром військової частини НГУ.

На основі усвідомлення (з'ясування) отриманого завдання та оцінювання елементів обстановки командир підрозділу приймає рішення на організацію виконання завдань служби з ОГП відповідно до Наказів Міністерства внутрішніх справ [1, с. 2-3; 6, с. 2-4]. 
Крім основних питань, які командир підрозділу відбиває у своєму рішенні, основна увага повинна приділятися підготовці особового складу військових нарядів, організації взаємодії та зв'язку під час несення служби з ОГП.

Розглянемо, які права й повноваження надаються військовослужбовцям НГУ під час самостійного несення служби на маршрутах патрулювання.

Відповідно до п. 1 ч. 1 ст. 13 Закону України «Про Національну гвардію» [3, с. 9-10] військовослужбовці НГУ мають право в разі залучення до виконання завдань, здійснювати превентивні й поліцейські заходи примусу.

Ст. 31 Закону України «Про національну поліцію» [7, с. 11] передбачений вичерпний перелік превентивних поліцейських заходів і загальні вимоги до їх застосування. Але водночас ця стаття в ч. 2 містить загальну вимогу до застосування таких заходів, а саме що під час проведення превентивних поліцейських заходів поліція зобов'язана повідомити особі про причини застосування до неї превентивних заходів, а також довести до ії відома нормативно-правові акти, на підставі яких застосовуються такі заходи.

Ураховуючи те, що п. 1 ч. 1 ст. 13 Закону України «ПроНаціональнугвардію» [3, с.9]використовує формулювання «здійснювати превентивні й поліцейські заходи примусу відповідно до Закону України «Про Національну поліцію», то здійснення військовослужбовцями (НГУ) поліцейських заходів відбувається з дотриманням вимог до поліцейських заходів, які висуваються й до самих поліцейських. Отже, перед здійсненням поліцейського заходу патрульний-військовослужбовець повинен повідомити причину застосування такого заходу (наприклад, під час вимоги пред'явлення документів для перевірки військовослужбовець НГУ зобов'язаний навести одну з підстав, передбачених ч. 1 ст. 32 Закону України «Про Національну поліцію», та повідомити конкретні обставини, що підтверджують наведені норми Закону).

Необхідно визначити, що під час несення служби на маршрутах патрулювання військові наряди стикаються з проблемними питаннями щодо затримання порушників (злочинців), оформлення на них документів і доставляння ї до територіальних органів поліції.

Відповідно до Доручення Міністра внутрішніх справ [4, с. 4] начальник військового наряду $(\mathrm{HBH})$ через лінію «102» або через ЧВН (НГВН) викликає до місця події в разі виявлення осіб, які підозрюються у вчиненні злочину, слідчо-оперативну групу (в разі виявлення осіб, які вчинили адміністративне правопорушення), наряд патрульної поліції для прийняття ними рішення щодо подальших дій стосовно правопорушника (винесення попередження, складення протоколу про адміністративне правопорушення, доставляння до територіального органу поліції тощо).

Як показує проведене дослідження самостійного несення служби військовими нарядами НГУ, в разі різких змін обстановки на маршрутах патрулювання виклик і своєчасне прибуття слідчо-оперативної групи, наряду патрульної поліції інколи відбувається не своєчасно. Це пов'язано з одночасним викликом декількох військових нарядів на затримання, коли в цей час слідчо-оперативна група, наряд патрульної поліції знаходиться на інших маршрутах для надання допомоги ВН. Ураховуючи такі обставини, військові наряди на деякий час залишаються на одинці з порушником (злочинцем), що сприяє скупченню зацікавлених осіб, які намагаються всілякими способами завадити затримання. У зв'язку із цим військовому наряду доводиться самостійно приймати рішення щодо правопорушника (злочинця), що своєю чергою небезпечно для самого наряду.

Усе це пояснюється тим, що проведений аналіз відповідно до Закону України «Про Національну гвардію» [3, с. 9] і Закону України «Про Національну поліцію» дає підстави дійти висновків про те, що застосування превентивних поліцейських заходів військовослужбовцями Національної гвардії відбувається не тільки з можливістю використання різноманіття таких заходів, а й з обов'язковим дотриманням військовослужбовцями загальних умов їх застосування, викладених у ч. 2 ст. 31 Закону України «Про Національну поліцію». Недотримання цих вимог має наслідком незаконність застосування такого превентивного заходу.

Відповідно до ч. 1 ст. 42 Закону України «Про Національну поліцію» [7, с. 15-16] поліція під час виконання завдань, визначених цим Законом, уповноважена застосовувати такі заходи примусу: фізичний вплив (сила); застосування спеціальних засобів; застосування вогнепальної зброї.

Поліцейський за жодних обставин не може застосовувати заходи примусу, не визначені цим Законом (ч. 5 ст. 42 Закону України «Про Національну поліцію»). Водночас згідно із 4. 1 ст. 15 Закону України «Про Національну гвардію» [3, с. 10-11] військовослужбовці Національної гвардії України мають право застосовувати заходи фізичного впливу, а за виключної необхідності й спеціальні засоби, вогнепальну зброю в порядку й у випадках, передбачених цим Законом. 
Якщо ж порядок та умови застосування фізичної сили регулюються Законами однаково, то особливостями, які потребують уваги, є порядок, види й умови застосування спеціальних засобів військовослужбовцями Національної гвардії, зокрема під час здійснення заходів щодо забезпечення громадського порядку.

Незважаючи на те, що під час провадження діяльності щодо забезпечення громадського порядку військовослужбовці здійснюють використання спеціальних засобів відповідно до ст. 45 Закону України «Про Національну поліцію» [7, с. 16-18], все ж таки для Національної гвардії діє спеціальний Закон «Про Національну гвардію України».

Згідно із ч. 2 ст. 17 Закону України «Про Національну гвардію» [3, с. 12-13] перелік і правила застосування спеціальних засобів встановлюються Кабінетом Міністрів України, що само по собі створює певні ризики в правовому регулюванні застосування спеціальних засобів, адже дозволяє здійснення такого регулювання на підзаконному рівні.

Наступною проблемою, незважаючи на рівень регулювання, є суперечність між постановою Кабінету Міністрів України № 1024 від 20 грудня 2017 р., якою затверджено Перелік і Правила застосування спеціальних засобів військовослужбовцями Національної гвардії під час виконання службових завдань, і ч. 5 ст. 42 ЗаконуУкраїни «Про Національнуполіцію». Адже на відміну від тринадцяти закріплених ч. 4 ст. 42 Закону України «Про Національну поліцію» спеціальних засобів відповідно до Постанови Кабінету Міністрів України [8, с. 1] передбачено можливість п'ятнадцяти спеціальних засобів, зокрема не передбачених Законом «Про Національну поліцію».

Також слід звернути увагу на абзац 2 п. 2 Закону України «Про Національну гвардію» [3, с. 10-11], який передбачає, що в разі залучення військовослужбовців Національної гвардії до виконання завдань з охорони громадського порядку застосування спеціальних засобівздійснюєтьсявідповіднодост. 45Закону України «Про Національну поліцію» [7].

Отже, порядок застосування спеціальних засобів все ж таки регулюється ст. 45 Закону України «Про Національну поліцію».

Висновки. Таким чином, розглянувши питання особливості організації самостійного несення служби з ОГП і шляхи їх розв'язання, необхідно констатувати, що забезпечення охорони громадського порядку на маршрутах патрулювання військовослужбовцями НГУ повинне мати нормативно-правовий та організаційний характер.
Отже, як вбачається з проведеного аналізу законодавства й вивчення практичного досвіду самостійного несення служби Національною поліцією України, військовими формуваннями з правоохоронними функціями іноземних країн Європи й світу щодо здійснення самостійного несення служби з ОГП військовослужбовцями Нацгвардії, проблемні питання все ж таки існують. Усунення зазначених проблем може бути забезпечено такими шляхами. Пропозиції: 1) формування єдиного стандарту забезпечення охорони громадського порядку, зокрема шляхом уніфікованого підходу до закріплення та, відповідно, реалізації заходів у цій сфері (за нинішніх обставин цілком виправданим вбачається розглядати як основу діяльності правоохоронних органів у сфері підтримання публічної безпеки й порядку положення Закону України «Про Національну поліцію»). Наслідком цього має стати окреслення сфери компетенції НГ України щодо забезпечення ОГП та усунення суперечностей між законами України «Про Національну гвардію України» й «Про Національну поліцію»; 2) доповнення ст. 263 Кодексу України про адміністративні правопорушення після слів «(Національною поліцією)» словами «а також Національною гвардією»; 3) для розв'язання цих проблемних питань і недопущення порушень вимог законодавства пропонується закріпити працівника поліції в зоні оперативного реагування на час самостійного несення служби з ОГП військовослужбовцями НГУ. Це дасть своєчасну допомогу військовим нарядам у правильності дій щодо порядку затримання порушників громадського порядку й доставлення в територіальні органи поліції, отримання своєчасної інформації про злочини та їх розкриття по «гарячих слідах», що також $€$ прерогативою військових нарядів Національної гвардії України.

Наприкінці зазначимо, що запропоновані нами шляхи усунення проблем щодо забезпечення охорони громадського порядку НГ України створить умови законності й, відповідно, ефективності діяльності останньої в зазначеній сфері. Разом із тим у межах однієї статті неможливо викласти всі особливості й шляхи удосконалення із забезпечення публічної безпеки й порядку НГ України, що зумовлює необхідність продовження наукових пошуків у цьому напрямі.

\section{ЛІТЕРАТУРА:}

1. Про затвердження Інструкції про організацію та несення служби з охорони громадського порядку та забезпечення громадської безпеки військовими частинами (підрозділами) Національної гвардії України : Наказ МВС України № 1089 від 24 грудня 
2019 р. / Міністерство внутрішніх справ України. URL: https://zakon.rada.gov.ua/laws/show/z0195-20\#Text.

2. Про затвердження Положення про військові частини і підрозділи з охорони громадського порядку Національної гвардії України : Наказ Міністра внутрішніх Справ України від 16 червня 2014 р. № 567, зареєстрований у Міністерстві юстиції України 3 липня 2014 р., за №729/25506 / Міністерство внутрішніх справ України. URL: https://zakon.rada.gov.ua/ laws/show/z0729-14\#Text.

3. Про Національну гвардію України : Закон України від 13 березня 2014 р. № 879-VII / Верховна Рада України. Відомості Верховної Ради України. 2014. №17. Ст. 594.

4. Про посилення заходів щодо забезпечення охорони громадського порядку та громадської безпеки, в населених пунктах України : Доручення Міністра внутрішніх справ України від 26 липня 2019 р. № 10309/01/20-2019.

5. Про затвердження Порядку організації взаємодії НГУ та НПУ під час забезпечення (охорони) публічної (громадської) безпеки і порядку : Наказ МВС № 773 від 10 серпня 2016 р., зареєстрований у Міністерстві юстиції України 07 вересня 2016 р. за № 1223/ 29353 / Міністерство внутрішніх справ України. URL: https://zakon.rada.gov.ua/laws/show/z1223-16\#Text.
6. Про затвердження Переліку основних документів, що відпрацьовуються в Національній гвардії України : Наказ командуючого НГУ № 550 від 18 жовтня 2019 р.

7.Про національну поліцію України : Закон України від 02 липня 2015 р. № 565-XII / Верховна Рада України. Відомості Верховної Ради України. 2015. № 4. Ст. 20.

8. Про затвердження переліку та Правил застосування спеціальних засобів військовослужбовцями Національної гвардії під час виконання службових завдань : Постанова КМУ №1024 від 20 грудня 2017 р. / Кабінет Міністрів України. URL: https://zakon.rada.gov.ua/laws/show/1024-2017$\%$ D0\%BF\#Text

9. Іванцов В.О. Адміністративна відповідальність: узагальнюючий підхід до визначення поняття. Право і Безпека. 2014. № 3 (54). С. 48-53.

10. Лошицький М.В. Адміністративно-правові відносини в сфрері охорони громадського порядку : дис. ... канд. юрид. наук : 12.00.07. Київ, 2002. 181 с.

11. Горбач Д.О. Деякі питання організації діяльності військових фрормувань держави 3 правоохоронними функціями та можливості його використання в Україні. Вісник ХНУВС. 2014. № 4 (67). C. 25-34. 